\title{
RESPONSABILIDADE, ÉTICA E PROGRESSO SOCIAL
}

No Boletim Eletrônico № 997 da Sociedade Brasileira de Química, o Secretário Geral anunciou que a $35^{\mathrm{a}}$ Reunião Anual da SBQ ( $35^{\mathrm{a}}$ RASBQ) será realizada em Águas de Lindóia - SP, entre os dias 28 a 31 de maio de 2012. O tema dos trabalhos e debates será "Responsabilidade, Ética e Progresso Social".

É crescente o número de eventos que procuram discutir conceitos, práticas e indicadores de responsabilidade e ética associados ao progresso social e econômico. Portanto, o tema proposto é muito apropriado, pois envolve três conceitos atuais e importantes para a sociedade e, sem dúvida, os membros da SBQ terão muito a debater sobre esses assuntos, tanto com os estudantes como com os profissionais.

A responsabilidade é um dos pilares sociais e pode ser subdividida em individual e coletiva. Espera-se que governos, empresas e profissionais sejam guiados por um código de responsabilidade e ética que garanta que seus desempenhos sejam positivamente reconhecidos pela sociedade. Então, o governo tem responsabilidade nas políticas públicas, práticas, nos indicadores e nas fiscalizações; as empresas têm responsabilidade com os produtos que disponibilizam para os consumidores e os profissionais são responsáveis por seus atos.

Em outro viés, muito se discute sobre a responsabilidade e a ética do desenvolvimento científico, mas a ciência é, em realidade, um conjunto diversificado de áreas sistematicamente organizadas, onde a Química é uma das áreas centrais. Como então discutir as responsabilidades da Química no cotidiano sabendo que todos os processos da vida são controlados por reações químicas?

A Química está na interface entre o progresso social e o avanço científico e tecnológico e, desta forma, sujeita às influências deste processo que, na maioria das vezes, é altamente positivo. Porém, no processo de avanço muitas falhas graves ocorreram no passado e ainda continuam ocorrendo e, consequentemente, fortes questionamentos no aspecto da responsabilidade com o meio ambiente têm sido levantados e muitas vezes acabam chegando à apreciação do Poder Judiciário. Certamente, a imagem da Química não tem sido das melhores. Para o público, ela é sinônimo de chaminés fumegantes e rios envenenados. Algumas empresas, através de propaganda enganosa, utilizam a palavra química em publicidade para ressaltar coisas ruins. A seguinte frase retirada de uma propaganda de cosmético mostra a degradação que se alcançou: "Excesso de química no cabelo, química mal retirada dos fios, química incompatível com a química anterior...” Felizmente há outros que vêem a Química pelo lado positivo e a cantam em verso e prosa, como na recente canção de Luan Santana "Que tal a gente agora misturar a nossa cor/ Pra ver a combustão, a química do nosso amor/ Eu e você, quer pagar pra ver?"

Tendo como paradigma que a compreensão humana sobre a natureza é baseada em nosso conhecimento da Química, a sua responsabilidade aumenta. Obviamente, quando se fala em responsabilidade da Química se quer abranger as responsabilidades dos governos, empresas, professores, escolas e universidades. Cada um dentro da sua esfera de ação deve ter a consciência de que somente com atos equilibrados entre os objetivos econômicos, sociais e ambientais se pode alcançar o tão desejado progresso social, "construir um futuro e um mundo melhor",, e assegurar às gerações futuras uma melhor qualidade de vida. ${ }^{2}$

A ética se constitui em um conjunto de valores morais que procuram orientar o comportamento dos seres humanos em todas as situações. Desta forma, influencia a sociedade assim como é influenciada pela própria vivência dos cidadãos. A responsabilidade e a ética caminham junto, da mesma forma que o desenvolvimento das ciências e a ética. No entanto, a ciência que tem trazido soluções para os males da humanidade também tem criados muitos outros problemas, inclusive os de caráter ético sobre o que se pode e o que se deve fazer. A mídia tem divulgado desvios éticos, mas na maioria dos casos envolvendo as questões de ética nas publicações científicas. Esse assunto é preocupante e a Química Nova tem trazido essa discussão através de seus editoriais, ${ }^{3-5}$ sem usar de denuncismo e procurando levar aos leitores a informação de que problemas com desvios como cópia de textos sem a devida citação, autoplágio, manipulação de dados e conduta antiética podem causar danos irreparáveis a uma carreira profissional. Recentemente (16/9/2011), a FAPESP divulgou um CÓDIGO DE BOAS PRÁTICAS CIENTÍFICAS. ${ }^{6}$ Apesar desse código estabelecer "diretrizes éticas para as atividades científicas dos pesquisadores beneficiários de auxílios e bolsas da FAPESP”, seria muito interessante a sua divulgação entre todos os docentes e estudantes do país.

A Química é um importante instrumento para o desenvolvimento socioeconômico de um país e tem peso significativo na balança comercial. Recentemente, Galembeck mostrou em um editorial do J. Braz. Chem. Soc. que "não existe país com produção econômica vultosa que não tenha também uma grande produção química, e os países que são hoje os mais dinâmicos economicamente podem ser facilmente identificados pelo seu destaque na produção química."7 Os conhecimentos científicos e tecnológicos destacam os países mais avançados e economicamente mais fortes. No Brasil, a produção química é geradora de milhares de empregos e responsável por parte significativa do PIB. Desta forma, é responsável pelo progresso social e melhoria da qualidade vida, não só com a criação de novos medicamentos, defensivos agrícolas, novos materiais para aplicações médicas e eletrônicas dentre outros, mas também pelas riquezas geradas para os países.

Diante dos sérios problemas em educação, saúde, meio ambiente, desemprego e violência, o desejado progresso social tem que ser alcançado com responsabilidade e ética. Esse assunto está na pauta de discussão da SBQ.

Susana I. Córdoba de Torresi
Vera L. Pardini
Vitor F. Ferreira
Editores de QN

\section{REFEREÊNCIAS}

1. "Do petróleo à biomassa: soluções para um mundo melhor?" e "Química para um mundo melhor" foram os temas das $32^{\mathrm{a}}$ e $34^{\mathrm{a}}$ Reuniões Anuais da SBQ, em 2008 e 2010, respectivamente.

2. Relatório Brundtland da Organização das Nações Unidas.

3. Torresi, S. I. C.; Pardini, V. L.; Ferreira, V. F.; Quim. Nova 2008, 31, 197.

4. Torresi, S. I. C.; Pardini, V. L.; Ferreira, V. F.; Quim. Nova 2009, 32, 1371.

5. Torresi, S. I. C.; Pardini, V. L.; Ferreira, V. F.; Quim. Nova 2011, 34, 371.

6. http://www.fapesp.br/boaspraticas/codigo_fapesp0911.pdf, acessada em Outubro 2011

7. Galembeck, F.; J. Braz. Chem. Soc. 2011, 22, 195. 